\section{Science in Australia}

SIR - Your appraisal of science in Australia (Nature 375, 177-182; 1995) concluding "looks up and ahead" can only be the truth, given the sorry state of support for science, as viewed from the bench, over the past decade or more. The quality of Australian science remains remarkably high given the infrastructure and resources available and is a credit to scientists still working in that country.

You point out that Australian salaries are low by world standards yet science in Australia is more truly "international" than that elsewhere, and even that members of the Waite Institute in Adelaide appear to relate to Europe rather than Sydney. You are of course right. The reason is that many of the best scientists have to leave to pursue their career goals.

The drain to Europe and North America risks becoming a flood, and recent trends, such as the virtually annual reviews of CSIRO, crowding at the universities and the perennial Australian 'tall-poppy syndrome' will not slow it down. Australian scientists are replaced by temporary postdoctoral workers and other, largely British, academics seeking to enjoy the life 'down under'.

Australian science is impressive and has good reason to look up and ahead, but if all expatriate Australian scientists were still there with the resources they now enjoy elsewhere, what a story that would be.

Craig M. Liddell

New Mexico State University,

Department of Entomology, Plant

Pathology and Weed Science,

Box 30003/Dept 3BE,

Las Cruces,

New Mexico 88003-0003, USA

\section{Cerebral malaria}

SIR - We have found that most of the clinical isolates of Plasmodium falciparum from the recent epidemic of cerebral malaria in Rajasthan, India, were resistant to the most commonly used drug, chloroquine (21 out of 22). But we also found that all tested isolates among these resistant cases were sensitive to mefloquine (18 out of 18 ) as well as to quinine (10 out of 10$)$. Most of the clinical isolates were also sensitive to pyrimethamine/sulfadoxine (9 out of 10). Alternative antimalarial drugs were therefore still available, if anybody wished to use them.

Molecular studies (using PCR) based on knob protein gene show the presence of multiple strains of $P$. falciparum in these chloroquine-resistant isolates. We have found at least three distinct alleles (thus parasite strains) of this gene - one rare type, one common type (both reported earlier ${ }^{1}$ ) and one intermediate between these two. Some patients were even harvesting the mixture of both alleles (rare and common type). The finding of an intermediary chloroquine-resistant strain in one individual and a mixture of two strains (also resistant to chloroquine) in other patients may be an indication that the newer but chloroquine-resistant strains were emerging quickly during the epidemic. The emergence of chloroquine resistance seems to have resulted from doctors or state health workers prescribing $600 \mathrm{mg}$ chloroquine to malaria patients irrespective of species. This is certainly a low dose for $P$. falciparum malaria ${ }^{2}$.

The present epidemic is a result of poor management of malaria control programmes, as has been pointed out ${ }^{3}$. So it seems that not only has the wrong drug policy resulted in the emergence of multiple chloroquine-resistant strains but there has also been a high death toll because of the inability to detect them in time and to treat the patients with more appropriate antimalarial drugs such as mefloquine or quinine or even pyrimethamine. If it is true that some of these antimalarial drugs (for example mefloquine) are not available in India for such treatment, is it not time to review the policy?

\section{Y. D. Sharma}

\section{Rajiv Kant}

Department of Biotechnology,

All India Institute of Medlcal Sciences,

New Delhi 110 029, India

\section{R. Pillai}

M. A. Ansari

Usha Fillai

Malaria Research Centre,

22 Sham Nath Marg,

Delhi 110 054, India

1. Sharma, Y. D. Nature 373, 279 (1995).

2. A Note on Malaria Control and Prevention in Rajasthan (Medical and Health Service, Government of Rajasthan Jaipur, 1994).

3. Sharma, V. P. Nature 369, 700 (1994)

\section{Apoptosis again}

SIR - The word "apoptosis" was taken straight from Liddell and Scott's classical Greek-English lexicon complete with examples of its use in medicine by Hippocrates and Dioscorides (the physician, not the poet). It should therefore be pronounced with two 'p's and the accent on the antepenult. In a footnote to the landmark paper (Br. J. Cancer 26, 239-257; 1972) in which they introduced the term into modern science, J. F. R. Kerr, A. H. Wyllie and A. R. Currie give apoptosis in Greek letters but beginning with the wrong breathing and ending with the wrong sigma, and they suggest silencing the second $\mathrm{p}$ and accenting the penult because they wanted a word that would chime with mitosis: hence the present controversy.
David Latchman (Nature 375, 100; $1995)$ very properly prefers the observance of strictly defined criteria for the recognition of apoptosis to arguments about its pronunciation. Indeed, matters of definition and terminology go hand in hand. A consensus statement on apoptosis with 29 signatories (A. Alles et al. FASEB $J .5,2127-2128$; 1991) condemned the use of the terms "programmed cell death" and "cell suicide", but even some of the signatories failed to take much notice. The term 'developmentally programmed cell death' is acceptable because development is a sort of programme, but programmed cell death as an alternative term for apoptosis is not, unless a programme is considered to be any sequence of cause and effect, in which case, all deaths, including necrosis, would be covered. Most deaths involve mechanisms that are determined by the anatomy, physiology and chemistry of the thing dying; but if patient deaths are to be certified as 'programmed' or 'suicide', because genes play a major role, there may well be problems with the coroner.

Although many would object to an arbitrary change in the pronunciation of apoptosis, it is certainly necessary to give the term a closely defined meaning for modern scientific use. Naturally Liddell and Scott are silent on this topic, but as Humpty Dumpty (both 'p's pronounced) stressed to Liddell's daughter Alice "A word means just what I choose it to mean - neither more nor less. The question is which is to be master - that's all."

W. Beautyman

Beautyman Associates, 1201 Bethlehem Pike,

Flourtown, Pennsylvania 19031, USA

\section{Bats galore}

SIR - It is remarkable that echolocation in bats was treated as a new finding 50 years ago ("50 Years Ago", Nature 1 June 1995, page ix and 155, 672; 1945). A quarter of a century earlier, Hamilton Hartridge presented convincing arguments that bats used this method to avoid obstacles: in this case, threads hung across a room (J. Physiol., Lond. 54, 54-57; 1920). Hartridge (1886-1976) was one of Britain's most versatile physiologists, and is best remembered for his early work on haemoglobin and his later, rather idiosyncratic, views on human colour vision.

It is sobering to reflect that as late as 1919 Hartridge could obtain "sometimes between one and two hundred [bats] at a time" in his room at King's College, Cambridge, by leaving the windows open on summer nights.

\section{R. Cavonius}

Institut für Arbeitsphysiologie,

Ardeystrasse 67.

D-44139 Dortmund, Germany 